\title{
WestVirginiaUniversity
}

THE RESEARCH REPOSITORY @ WVU

West Virginia Agricultural and Forestry Experiment

Davis College of Agriculture, Natural Resources

Station Bulletins

And Design

$1-1-1973$

\section{Development of a wide swath lime and fertilizer spreader}

E. E. Primrose

Follow this and additional works at: https://researchrepository.wvu.edu/ wv_agricultural_and_forestry_experiment_station_bulletins

\section{Digital Commons Citation}

Primrose, E. E., "Development of a wide swath lime and fertilizer spreader" (1973). West Virginia Agricultural and Forestry Experiment Station Bulletins. 623T.

https://researchrepository.wvu.edu/wv_agricultural_and_forestry_experiment_station_bulletins/710 @ WVU. It has been accepted for inclusion in West Virginia Agricultural and Forestry Experiment Station Bulletins by an authorized administrator of The Research Repository @ WVU. For more information, please contact ian.harmon@mail.wvu.edu. 


\section{Development}

\section{of a Wide Swath}

Lime and Fertilizer

Spreader

Bulletin 623T

May 1973

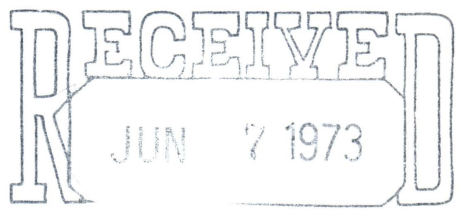

AG. ENGR. LIBRARY

WEST VIRGINIA UNIVERSITY

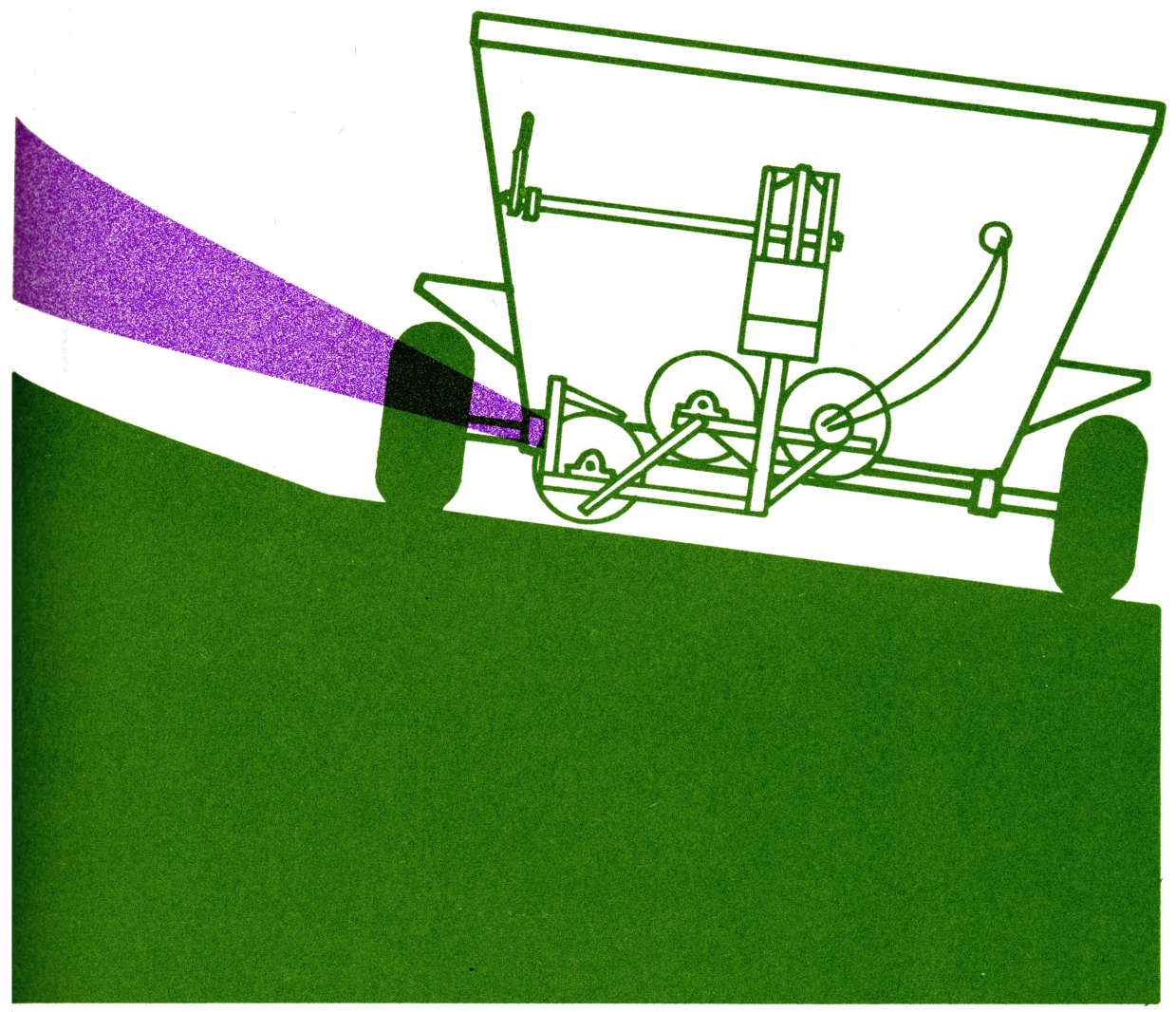

West Virginia University Agricultural Experiment Station 
West Virginia University

Agricultural Experiment Station

College of Agriculture and Forestry

R. S. Dunbar, Jr., Director

Morgantown 


\title{
Development of a Wide Swath Lime and Fertilizer Spreader
}

\author{
E. E. Primrose, R. C. Reeder, \\ H. E. Shoemaker, and R. G. Diener ${ }^{1}$
}

Hillside pastures are a valuable asset to the agriculture of West Virginia. However, of the 1,837,000 acres of permanent pasture 42 per cent is inaccessible for liming and fertilizer by conventional equipment (West Virginia Soil and Water Needs Inventory, 1970). Lack of equipment to properly manage the steep pasture lands has been one of the factors in some 735,807 acres reverting to forest lands since 1958.

West Virginia's lime needs amounted to 549,750 tons in 1960. However, only 143,277 tons, or about 26 per cent, were applied (National Limestone Institute, 1973). Of the 84,000 acres of pasture tested in the WVU-Allegheny Highlands Project, 85 per cent would benefit from lime, and 37 per cent needed lime additions before much response from phosphorus fertilization could be expected (Maxwell, 1971).

The most common method of applying agricultural lime is with spinner or gravity spreaders. Spinner spreaders have a limited swath width and do not give a totally satisfactory distribution, while the gravity spreaders are limited to their width. Aerial application has been deemed unfeasible because of the high application rates necessary, and correspondingly high cost. In addition, it is exceedingly hard to obtain an acceptable distribution with either spinner spreaders or aerial application because of the fine particle sizes of most limes.

The farmer may have limited access with conventional machines on some parts of this very steep pasture land using natural benches. These benches resulted from erosion and are usually formed from slippage and erosion of the red clay shale or Upshur complex soils (USDA Soil Survey, Jackson and Mason counties, 1961, and Wood and Wirt counties, 1970).

In many cases if benches are not present, a farmer can still cover most of his land by applying lime and fertilizer from the top and bottom of the hill if a long

${ }^{1}$ Test and Development Engineer, International Harvester Company, Hinsdale, Illinois (formerly Graduate Research Assistant, Division of Resource Management); Agricultural Engineer, West Virginia Department of Agriculture, Charleston, West Virginia (formerly Graduate Research Assistant, Division of Resource Management, Agricultural Experiment Station, WVU); Graduate Research Assistant, Department of Mechanical Engineering and Engineering Mechanics, WVU (formerly Graduate Research Assistant, Division of Resource Management); and Associate Agricultural Engineer, Agricultural Experiment Station, WVU. 
throw spreader is available. Maxwell (1971) estimated that of the cooperating farms in the WVU-Allegheny Highlands Project in Upshur and Randolph counties only a quarter to a third of the land could be covered using conventional equipment. He further estimated that if a 100-foot throw spreader was avail. able, a third to a half of the land could be covered.

A belt thrower was considered best suited to meet the need for a low cost, long distance throwing applicator for lime and fertilizer. By driving such a spreader along natural benches or level areas on most steep slopes the belt mechanism was used to throw fertilizer up or down the slope.

The belt spreader with its long throwing distance could be more suitable than other spreaders such as the spinner or liquid types for covering hillsides.

\section{OBJECTIVES}

The objectives of this study were:

1. To design a belt fertilizer thrower capable of throwing lime and fertilizer 100 feet.

2. To design a deflector mechanism to give an even distribution over the throwing distance.

3. To develop new liming materials for wide swath distribution with the high speed belt spreader.

\section{Design of Belt Spreader}

\section{PROCEDURE}

The thrower mechanism (Figure 1) consisted of a two-pulley system with a center steel hold-down wheel. Pulleys were $121 / 4$ inches in diameter by 10 inches wide and were crowned and dynamically balanced.

The pulleys were supported by $13 / 16$-inch shafts and heavy duty selfaligning bearings. The hold-down wheel was constructed with a flat, rather than crowned, surface to give uniform pressure across the belt width and help reduce the crushing of particles (Reeder, 1971).

A Vickers* Model MFB-10-FUY-30 hydraulic motor requiring 18.5 gallons per minute at 3,200 revolutions per minute was used to drive the thrower mechanism.

The deflector (Figure 2) consisted of nine one-inch wide fingers. These fingers were all fully adjustable to obtain the best possible distribution (Shoemaker, 1971).

The new thrower mechanism was mounted on a modified Willmar Manufacturing Co. (Willmar, Minnesota) Model 4 plus 1 Spreader chassis. The only modification was to remove the brackets which held the centrifugal spinners.

\footnotetext{
*Trade names and the names of commercial companies are used in this paper solely to provide specific information. Mention of a trade name does not constitute a guarantee or warranty of the product by West Virginia University or an endorsement by the University over other products not mentioned.
} 


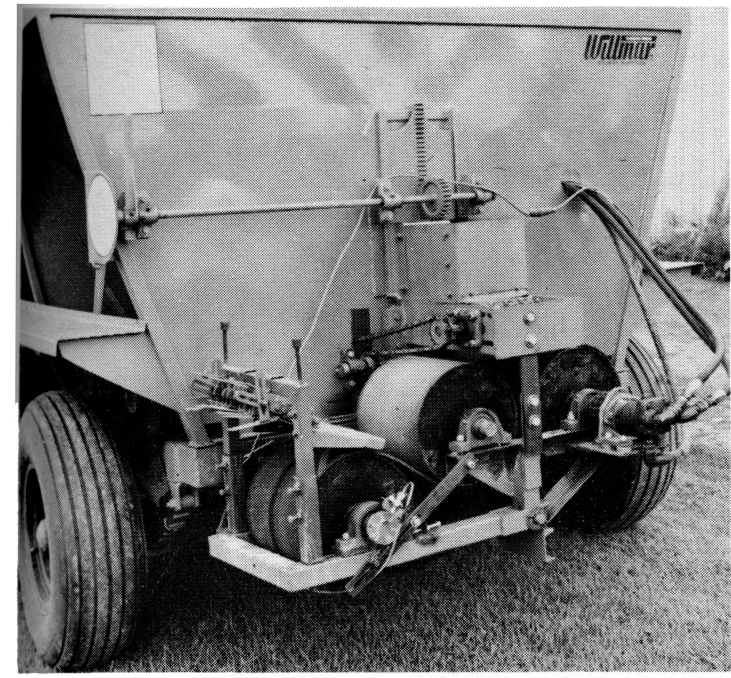

\section{Figure 1. High Speed Belt Spreader}

Figure 2.

Deflector Fingers on Belt Spreader

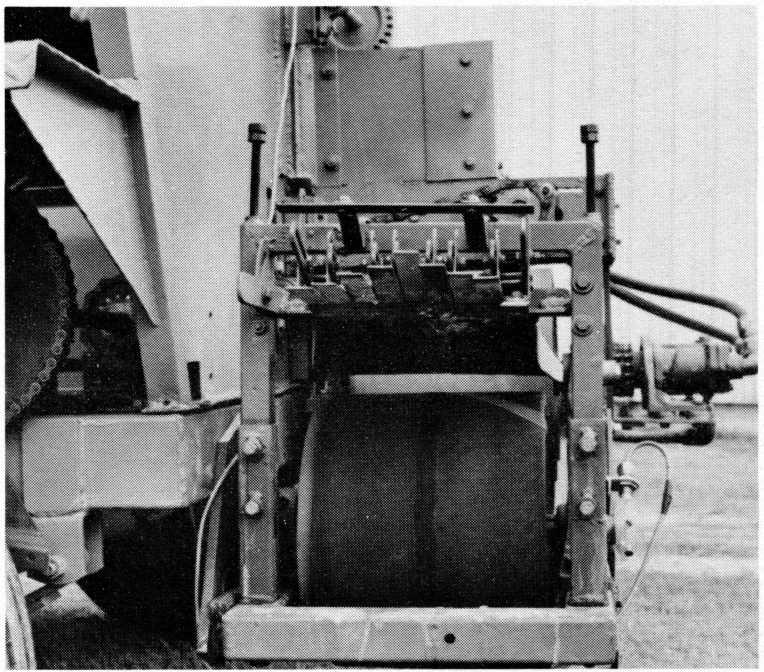

\section{Determination of the Optimum Belt Angle}

Before materials could be evaluated the optimum belt projection angle (Figure 3) had to be evaluated. The effect of initial inclination angle to horizontal distance along a trajectory shows the optimum launch angle to be a range from 33 to $45^{\circ}$ (Figure 4, Shoemaker, 1973). The optimum angle of $35^{\circ}$ was used because it obtains essentially the same displacement as the higher angles and has the added advantage that it lowers the particle trajectory and the particles are less affected by wind. This was also confirmed by experimental data 


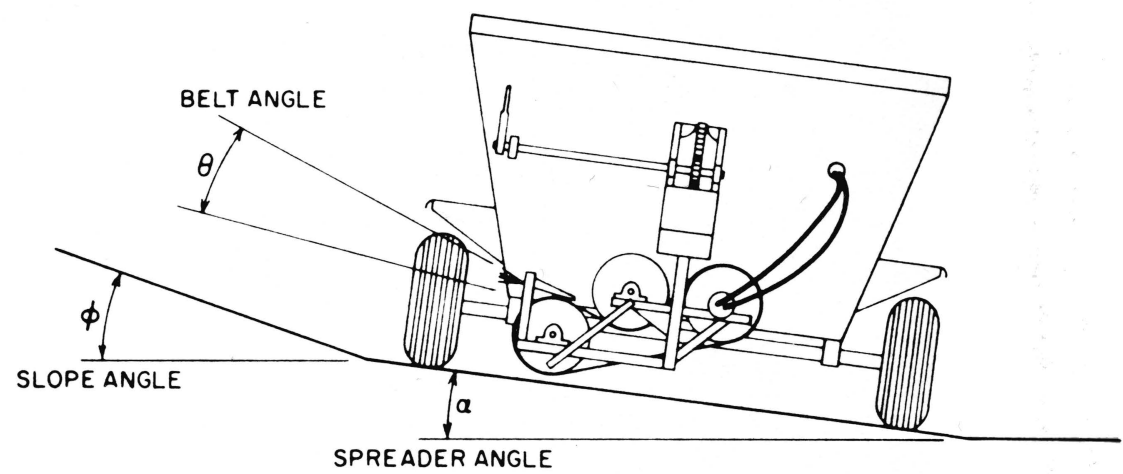

Figure 3. Rear View of Spreader, Showing Slope, Belt, and Spreader Angles

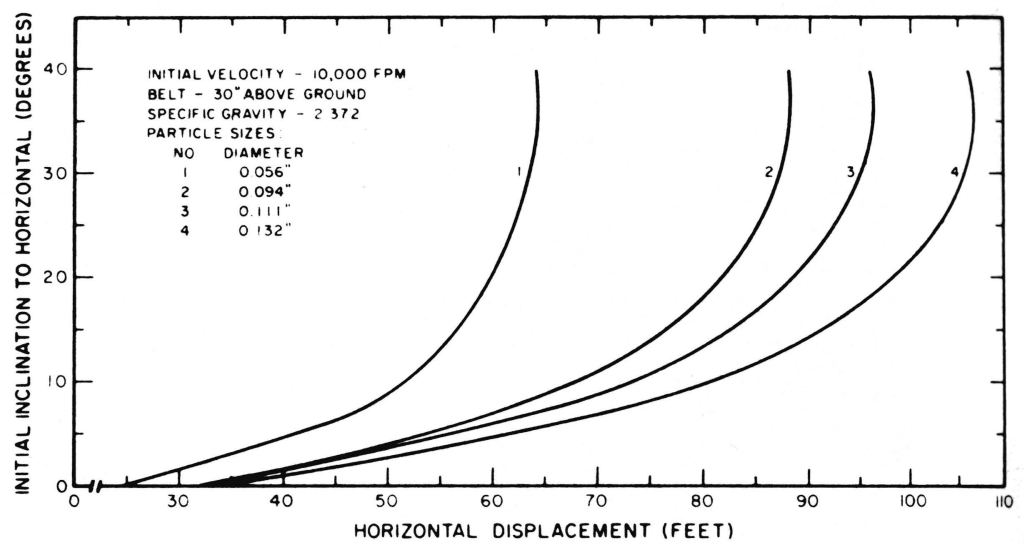

Figure 4. Effect of Initial Launch Angle on Horizontal Distance Thrown

for various values of spreader angles $\alpha$ and slope angles $\phi$ which had little effect on selection of the belt angle, $\theta$.

\section{EXPERIMENTAL PROCEDURE}

The WVU belt spreader was equipped with the adjustable deflector for easy changing for distribution improvement and for different types of lime and fertilizers. The belt speed was set to 10,000 feet per minute to obtain greater throwing distances. The throwing angle was set at the optimum throwing angle of $35^{\circ}$.

\section{Testing Procedures}

The ASAE Standard Testing Procedures were followed throughout the test- 
ing procedures with some minor variations (American Society of Agricultural Engineers Standard Test Procedure for Dry Fertilizer Spreaders, 1969).

Catching Trays-The ASAE Collection Tray was built and used in all the tests (Figure 5). These trays were placed at five-foot intervals up to 100 feet distance in two rows with approximately 15 feet between rows.

Data Collection-Two passes were made over the trays for each test and then the fertilizer samples from the trays were collected and weighed to the nearest 0.1 gram.

Spreader Operation-The belt thrower was brought up to speed and held constant using a Power Instruments, Inc., Model G-813-FXB magnetic pickup and a Hewlett Packard Model 5325B electronic counter at 10,000 feet per minute. All passes over the trays were at a ground speed of $33 / 4$ miles per hour.

\section{Fertilizer Variables Tested}

Types of Fertilizer Tested-There were four types of fertilizers tested. Ammonium nitrate (33.5-0-0) manufactured by Farmers Chemical Association, Inc.; triple super phosphate (0-46-0) manufactured by Central Farmers Fertilizer Company; muriate of potash $(0-0-60)$ manufactured by Central Farmers Fertilizer Company; and mixed manufactured analysis (5-10-10) manufactured by Southern States Cooperative, Inc. (Figure 6).

These four fertilizers were chosen because of their different characteristics. The first three represent the three plant nutrients needed by all plants. The last one was chosen because it is a widely used fertilizer in West Virginia and many other states.

These fertilizers varied considerably with regard to particle size, particle density, and particle shape. Table 1 gives the physical properties of the fertilizers.

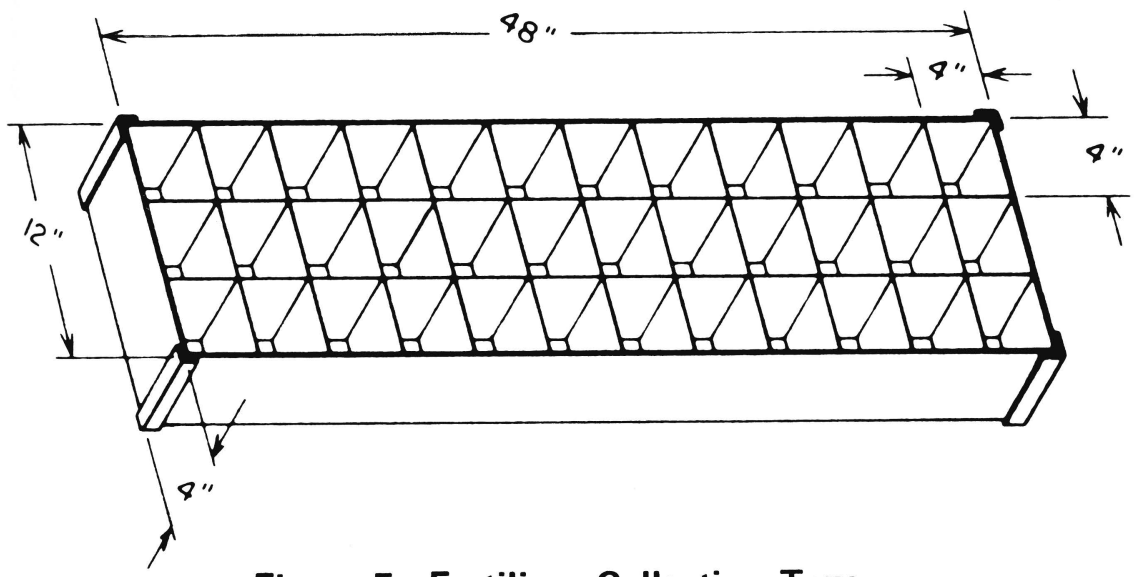

Figure 5. Fertilizer Collecting Tray 


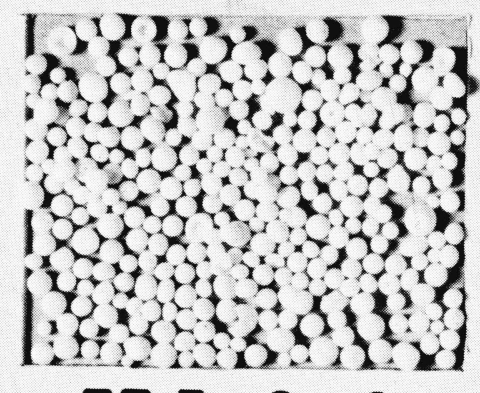

33.5-0-0
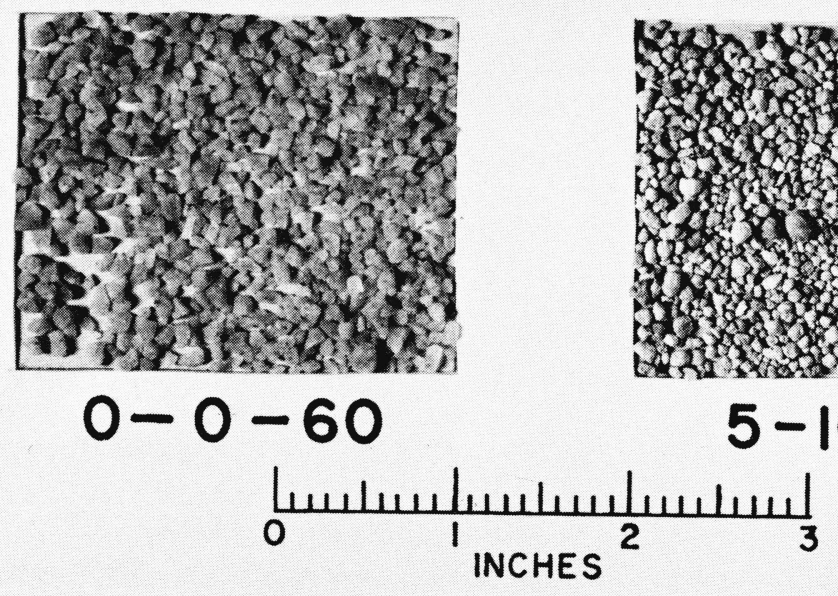

Figure 6. Fertilizer Materials Used

\section{3}
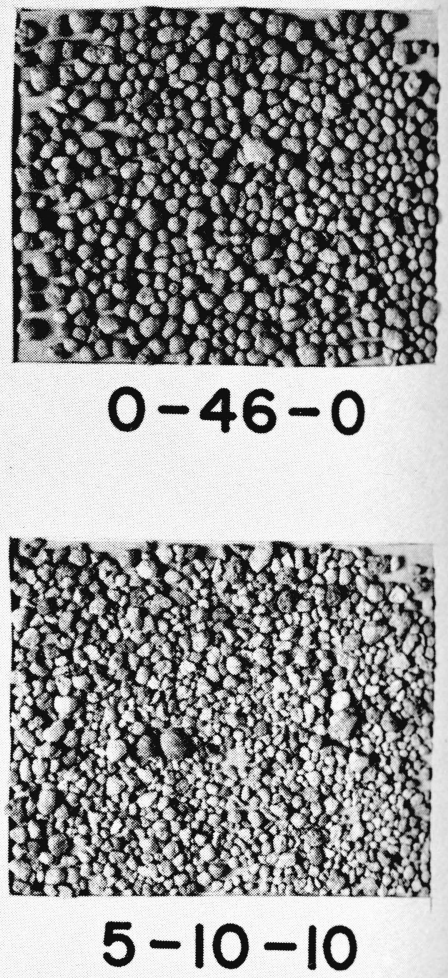
TABLE 1

Physical Properties of the Fertilizers Spread

\begin{tabular}{|c|c|c|c|c|}
\hline Fertilizer & $\begin{array}{l}\text { Specific } \\
\text { Gravity }\end{array}$ & $\begin{array}{c}\text { Particle } \\
\text { Density } \\
\text { (gram/cc) }\end{array}$ & $\begin{array}{c}\text { Bulk } \\
\text { Density } \\
\left(\mathrm{lb} / \mathrm{ft}^{3}\right)\end{array}$ & $\begin{array}{l}\text { Particle } \\
\text { Shape }\end{array}$ \\
\hline $\begin{array}{l}\quad 33.5-0-0 \\
\text { Ammonium Nitrate }\end{array}$ & 1.768 & 1.768 & 50.5 & Spherical Prills \\
\hline $\begin{array}{l}\text { 0-46-0 } \\
\text { Triple Super } \\
\text { Phosphate }\end{array}$ & 2.311 & 2.311 & 65.6 & $\begin{array}{l}\text { Irregular Spherical } \\
\text { Particles }\end{array}$ \\
\hline $\begin{array}{l}\text { 0-0-60 } \\
\text { Muriate of Potash }\end{array}$ & 2.054 & 2.054 & 61.2 & $\begin{array}{l}\text { Irregular Cubicle } \\
\text { Particles }\end{array}$ \\
\hline $5-10-10$ & 2.372 & 2.372 & 67.0 & $\begin{array}{c}\text { Irregular Spherical } \\
\text { Particles }\end{array}$ \\
\hline
\end{tabular}

TABLE 2

Lime Materials for Evaluation and Their Physical Properties

\begin{tabular}{|c|c|c|c|c|}
\hline Materials & $\begin{array}{c}\mathrm{CaCO}_{3} \\
\text { Equivalent } \\
\text { (Per Cent) }\end{array}$ & $\begin{array}{c}\text { Bulk } \\
\text { Density } \\
\left(\mathbf{l b} / \mathbf{f t}^{3}\right)\end{array}$ & $\begin{array}{l}\text { Specific } \\
\text { Gravity }\end{array}$ & $\begin{array}{c}\text { Cost } \\
\text { Per Ton }\end{array}$ \\
\hline $\begin{array}{l}\text { Agricultural } \\
\text { Ground } \\
\text { Limestone }\end{array}$ & 89 & 97 & 2.75 & 4.50 \\
\hline Damp Lime & 97.6 & 105 & 2.51 & 8.00 \\
\hline Damp Lime & $\begin{array}{c}100 \\
\text { (Wet Basis) }\end{array}$ & 104 & 2.42 & 6.00 \\
\hline $\begin{array}{l}\text { Pelleted } \\
\text { Float }\end{array}$ & 80 & 79 & 2.77 & $1.00 *$ \\
\hline $\begin{array}{l}\text { Pelleted } \\
\text { Germany Valley } \\
\text { Rock Dust }\end{array}$ & 98 & 80 & 2.77 & $12.00^{*}$ \\
\hline
\end{tabular}

*Does not include cost of pelleting. 


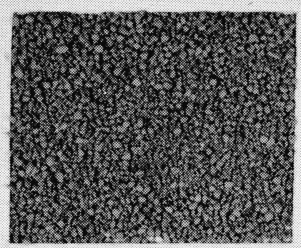

PELLETED FLOAT

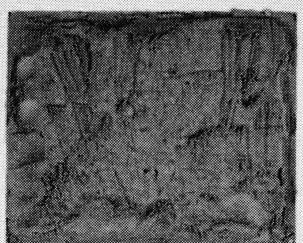

AGRICULTURAL LIME

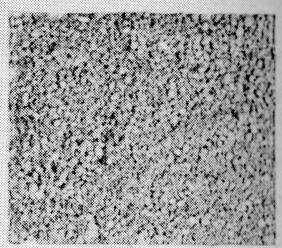

PELLETED ROCK DUST

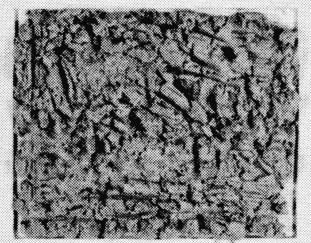

BASIC DOLOMITE

DAMP LIME

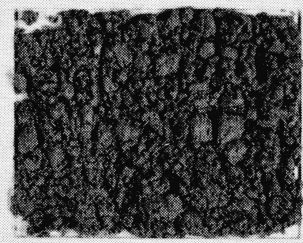

NEW JERSEY ZINC DAMP LIME

Figure 7. Liming Materials Used

Pelleted Lime-A new liming material was developed for this research using the Compaction/Granulation Process of the Komarek-Greaves Company, Rosemont, Illinois 60018. The process involved the compaction of the raw material into a narrow ribbon under high pressure. The thin ribbon is then granulated or broken up and the size fractions required are removed. Any fines are recompacted and oversize particles are regranulated. Through close control of the granulation process, the size of the particles or pellets can be regulated to obtain a particle with acceptable flight characteristics.

If necessary a small amount of binder may be used in the compaction process. While the pellets were the same size, and showed nearly the same sieve analysis, they differed in some physical properties. On two runs, the float showed an average Rimac Compression strength of $75 \mathrm{lbs}$. per square inch. The Germany Valley rock dust showed an average strength of $\mathbf{5 0}$ pounds per square inch. The particles also exhibited slightly different abrasion indices.

\section{Distance Tests}

The distance a material could be thrown was determined by the average of three trials or replications. The material was collected in catching trays at intervals of five feet up to 125 feet. Trays were placed two wide with the centerline of the double row in the center of the line of flight of the particles from the belt spreader. 
The material was weighed to the nearest gram. The distance a material was hrown was compared using the average distance to the peak of the distribution. These tests gave a good indication of the relative distance that different materials muld be thrown.

The belt was run at 10,000 feet per minute, and was set at the optimum ngle for maximum throwing distance of 35 degrees (Reints and Yoerger, 1965 and Shoemaker, 1973). These tests were run without the deflector in position.

\section{Distribution Tests}

These tests were run by aligning the spreader and catching trays exactly as for the distance tests. However, in these tests the deflector was adjusted to give a uniform distribution.

A coefficient of variation of less than 15 per cent (Glover and Baird, 1970) was attempted. This would mean that for a lime application of 2,000 pounds per jcre and a $\mathrm{CV}=15$ per cent that the actual application rate would vary between 1,700 and 2,300 pounds per acre, 68 per cent of the time.

\section{RESULTS}

\section{Fertilizer}

As the application rate increased, the horizontal displacement tended to increase for all four fertilizers, ammonium nitrate, triple super phosphate, muriate of potash, and 5-10-10. The least affected was ammonium nitrate.

The larger, more dense particles travel the farthest. Thus, blended fertilizers are separated and both chemically and physically uniform distributions are impossible. However, mixed analysis fertilizers such as 0-46-0 and 5-10-10 are manufactured so that each pellet is chemically similar, and they gave an excellent distribution. Fertilizers such as ammonium nitrate (33.5-0-0) which change hardness and surface friction characteristics with changes in the weather make it more difficult to design a deflector. While potash does not change characteristics as does nitrate, it is irregular in shape and cannot be thrown as far × $0-46-0$ or 5-10-10 nor with as much regularity.

Deflector Studies-Using the deflector it was possible to obtain a coefficient of variation as low as 10 per cent in regular field tests. Figure 8 shows a typical distribution of nearly 100 feet with 5-10-10 fertilizer.

\section{Lime}

Effect of Rate of Application -Figure 9 shows the effect of application rate on the distance a material can be thrown. In all cases, as application rate increased, the distance a material could be thrown also increased. At all application rates, the New Jersey damp lime was thrown the farthest. However, at 6,000 pounds per acre, the Basic Dolomite damp lime was thrown nearly as far. With a 


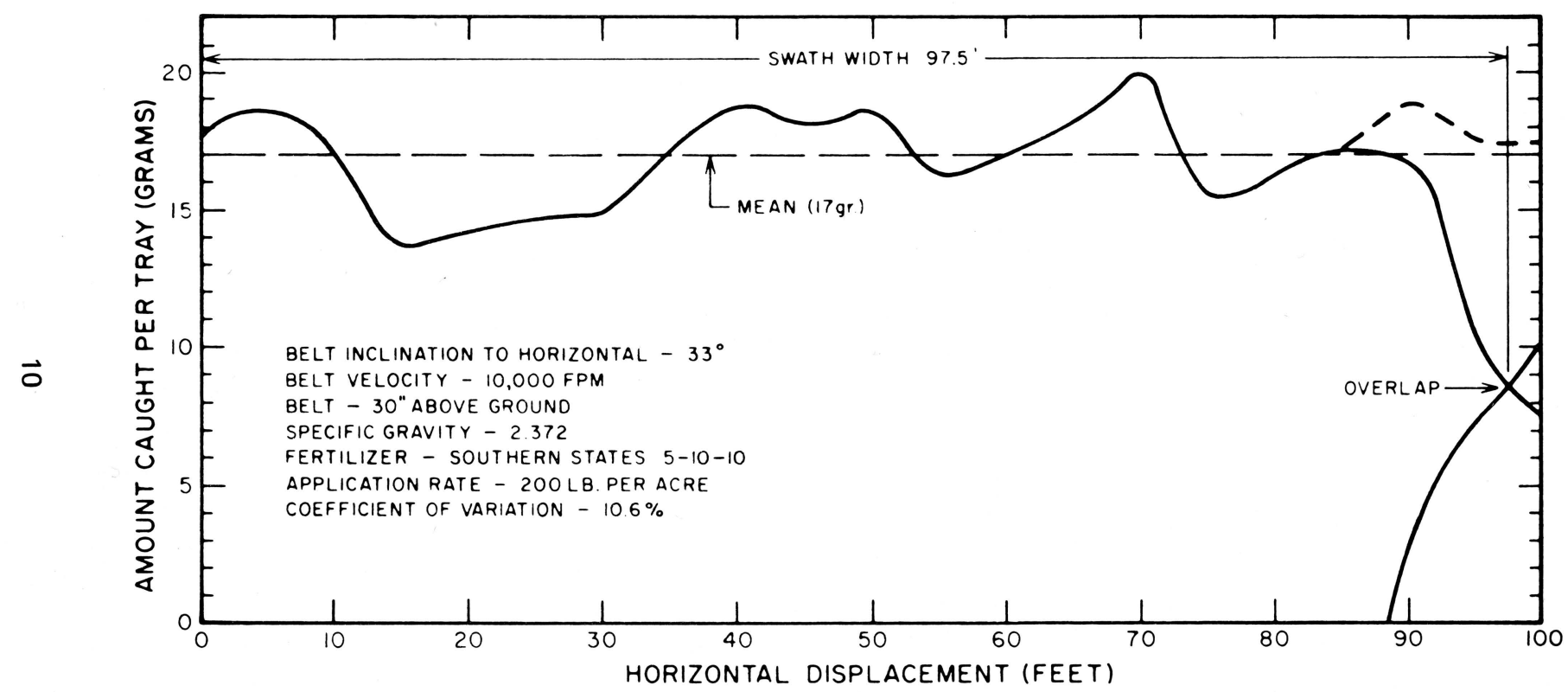

Figure 8. Sample Fertilizer Distribution Pattern Using One Set of Deflector Finger Settings 


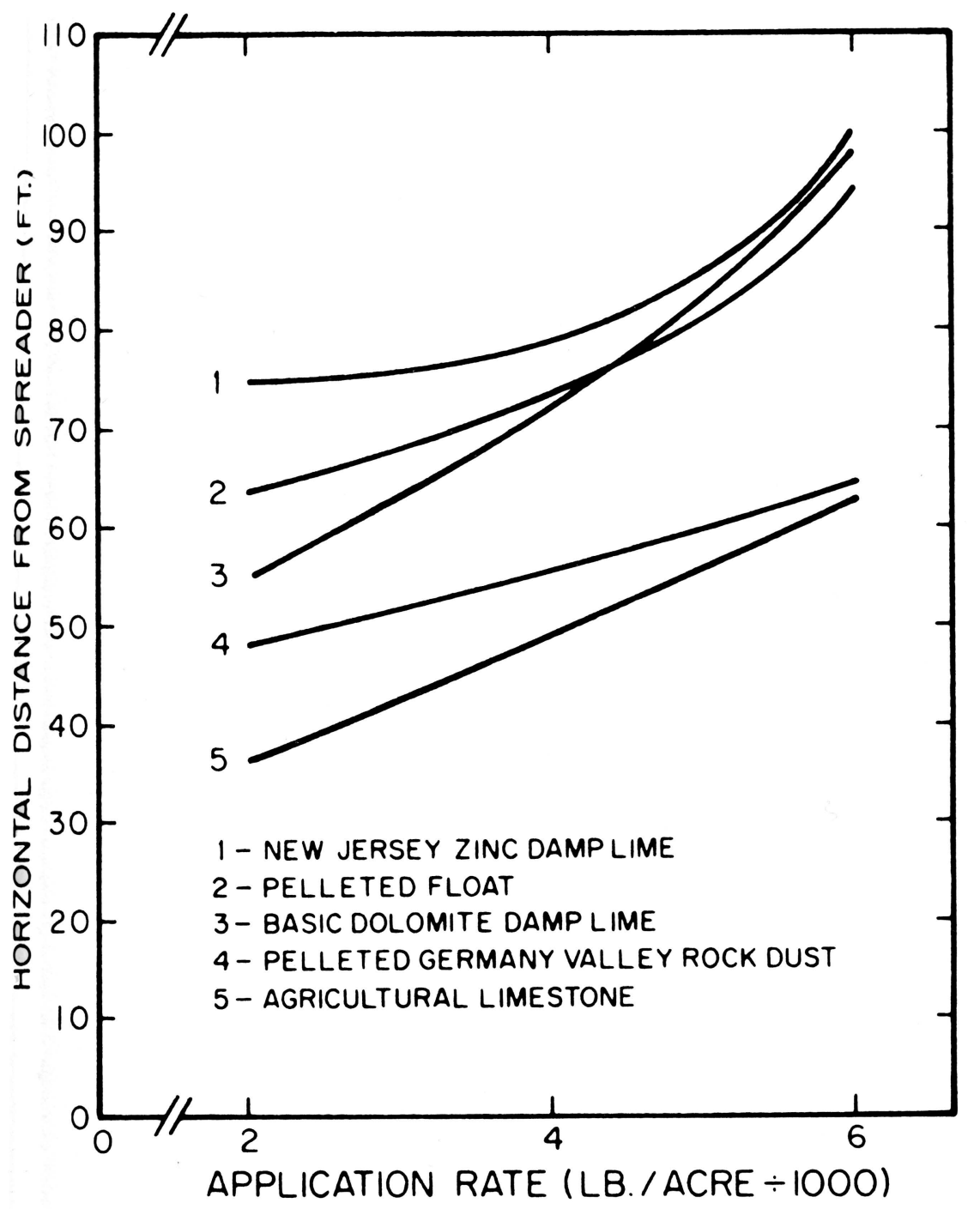

Figure 9. Effect of Application Rate on the Distance Difference Materials Can Be Thrown

much finer sieve analysis, the basic dolomite product benefited more from increased application rate than any other of the products tested.

Effect of Moisture Content of Damp Lime-The damp limes were discharged from the belt thrower as a wad or slug rather than thrown as individual small particles. The material spread out much less than the pellets or the agricultural lime when thrown at the same application rate. When the damp limes were 
thrown at a moisture content less than 9-12 per cent they acted more as a group of single particles than as a slug or wad. Therefore, a 9-12 per cent moisture content was maintained during the tests.

\section{Swath Widths}

The swath width was calculated using overlap on the outer ends of the distribution pattern. The computer program of Shoemaker (1971) performed the overlap when calculating the coefficient of variation. For example, when calculating the coefficient of variation at a swath width of 80 feet the amount of material caught at 85 feet was added to that caught at 75 feet, 90 to 70 feet, 95 to 65 feet, and so on. The amount caught at 80 feet was doubled, because it would be applied twice, once by each passage of the spreader.

The New Jersey zinc damp lime gave the widest swath width of 82.5 feet. Basic dolomite damp lime was second longest with a width of 62.5 feet, while the two pelleted materials were best at a 57.5-foot swath width. The results are shown in Figure 9.

\section{Uniformity of Distribution}

The basic dolomite damp lime had the most even distribution. A coefficient of variation of 13.2 per cent at a swath width of 60 feet was observed. The other three materials had coefficients of variation that ranged from 17.5-20 per cent. While these are not as low as the 15 per cent set as acceptable by Glover and Baird (1970), they improved drastically the coefficients of variation obtained with no deflector. The use of a deflector also reduces the swath width, as well as improves the distribution.

\section{CONCLUSIONS}

1. The high speed belt spreader can deliver up to 90 -foot swath widths with 33.5-0-0, 0-46-0, and 5-10-10 and 65-foot width for 0-0-60 fertilizers. In all cases the distribution is uniform, with coefficients of variation as low as 10 per cent.

2. The New Jersey zinc damp lime could be thrown farther than other liming materials tested regardless of application rate. It gave a swath width of 82.5 feet with an acceptable coefficient of variation of about 18 per cent.

3. As application rate increased, the distance both lime and fertilizer material could be thrown also increased. 


\section{REFERENCES}

ASAE Agricultural Chemical Application Committee 1969. ASAE Standard Test Procedure for Dry Fertilizer Spreaders.

Glover, J. W. and J. V. Baird. 1970. The Performance of Spinner Type Fertilizer Spreaders. ASAE Paper 70-655.

Maxwell, R. H. (Director, WVU-Allegheny Highlands Project) 1971. Personal Conversation.

National Limestone Institute. 1973. News Release, January 5, 1973. 1315 Sixteenth Street, N.W., Washington, D.C. 20036.

Reeder, R. C. 1969. Design and Development of a Wide Swath Fertilizer Spreader for Hillside Pastures. ASAE Paper 70-656.

Reints, R. E. and R. R. Yoerger, 1965. Trajectories of Seeds and Granular Fertilizers. Transactions of ASAE 10(2):213.

Shoemaker, H.D. 1973. Computer Design of Deflectors on a High Speed Belt Fertilizer Spreader. Transactions of ASAE 15(6):1049-1054.

Soil Survey-Jackson and Mason Counties, West Virginia 1961. USDA Soil Conservation Service in cooperation with WVU Agricultural Experiment Station.

Soil Survey-Wood and Wirt Counties, West Virginia 1970. USDA Soil Conservation Service in cooperation with WVU Agricultural Experiment Station.

West Virginia Soil and Water Conservation Needs Inventory 1970. Published by the Soil Conservation Service, Morgantown, West Virginia. 


\section{[Blank Page in Original Bulletin]}

